Sains Malaysiana 50(5)(2021): 1329-1342

http://doi.org/10.17576/jsm-2021-5005-13

\title{
Effect of Sugar-Pectin-Citric Acid Pre-Commercialization Formulation on the Physicochemical, Sensory, and Shelf-Life Properties of Musa cavendish Banana Jam
}

(Kesan Formulasi Pra-Pengkomersialan Gula-Pektin-Asid Sitrik terhadap Fizikokimia, Deria, dan Jangka Hayat Jem Pisang Musa cavendish)

\author{
Wan AbD Al qadr Imad Wan-Mohtar, SARina Abdul Halim-Lim*, Joshini Pillai Balamurugan, Mohd \\ ZAHIRUdDIN MOHD SAAD, Nur ASYiQIn ZAHIA AZIZAN, Adi AINURZAMAN JAMALUdin \& Zul ILHAM
}

\section{ABSTRACT}

Cavendish banana is the second most cultivated species in Malaysia due to its high potassium and vitamin B6 content. However, there has been little commercialisation of Cavendish banana in jam making to date because of its unappealing physical characteristics and unsavoury taste. In the present study, response surface methodology was used to determine the optimum quantity of sugar (175-275 g)-pectin (3-7 g)-citric acid (150-234 mL) (SPC) on water activity, ${ }^{\circ}$ Brix, colour analysis, $\mathrm{pH}$, total titratable acidity (TTA), and sensory attributes of formulated banana jams. The amount of sugarpectin-citric acid was found to have an effect on the TTA and pH of the banana jams. Conversely, water activity and ${ }^{\circ}$ Brix were only affected by the amount of sugar. The lightness, $L^{*}$ of the banana jams was influenced by the quantity of pectin and the volume of citric acid added. Sensory analysis using 30 panellists showed that there were changes in the colour, taste, aroma, texture, and overall acceptability of banana jam depending on the amount of sugar used. In a shelf life study, banana jams stored at $4{ }^{\circ} \mathrm{C}$ were found to have a longer shelf life compared to those stored at $25^{\circ} \mathrm{C}$. Overall, the optimal formulation for a high-quality banana jam was $281.79 \mathrm{~g}$ of sugar, $4.13 \mathrm{~g}$ of pectin, and $264.66 \mathrm{~mL}$ of citric acid. This study constitutes the first report on the potential pre-commercialisation formulation for Cavendish banana jam production.

Keywords: Cavendish banana; jam; pectin; response surface methodology; sensory evaluation; shelf life

\section{ABSTRAK}

Pisang Cavendish ialah spesies pisang kedua terbanyak ditanam di Malaysia disebabkan kandungannya yang tinggi potasium dan vitamin B6. Namun, usaha pengkomersialan pisang ini terbatas disebabkan oleh rupa dan rasanya yang kurang menarik dan sedap. Kajian ini menggunakan kaedah gerak balas permukaan untuk menentukan nilai optimum kandungan gula (175-275 g)-pektin (3-7 g)-asid sitrik (150-234 mL) (SPC) terhadap aktiviti air, ${ }^{\circ}$ Brix, analisis warna, $\mathrm{pH}$, jumlah keasidan yang dapat dititrat (TTA) dan deria rasa bagi jem pisang yang dihasilkan. Kandungan gulapektin-asid sitrik didapati mempunyai impak terhadap TTA dan pH jem pisang. Sebaliknya, aktiviti air dan ${ }^{\circ}$ Brix hanya dipengaruhi oleh jumlah kandungan gula. Kepekatan warna, $L^{*}$ jem pisang ditentukan oleh jumlah pektin dan asid sitrik yang digunakan. Analisis deria rasa jem pisang dilakukan oleh 30 orang panelis dan mendapati perubahan dalam warna, rasa, aroma, tekstur dan penerimaan keseluruhan jem pisang bergantung kepada jumlah gula yang digunakan. Jem pisang yang disimpan pada suhu $4{ }^{\circ} \mathrm{C}$ dilihat mempunyai jangka hayat yang lebih lama berbanding dengan jem pisang yang disimpan pada suhu $25{ }^{\circ} \mathrm{C}$. Secara kesimpulannya, kadar optimum untuk menghasilkan jem pisang yang berkualiti tinggi adalah $281.79 \mathrm{~g}$ gula, $4.13 \mathrm{~g}$ pektin dan $264.66 \mathrm{~mL}$ asid sitrik. Kajian ini merupakan laporan pertama mengenai potensi formulasi pra-pengkomersialan untuk pengeluaran jem pisang Cavendish.

Kata kunci: Deria rasa; jangka hayat; jem; kaedah gerak balas permukaan; pektin; pisang Cavendish

\section{INTRODUCTION}

Banana is a fruit that grows extensively in the tropics and in many sub-tropical countries (Thompson et al. 2019). The Cavendish subgroup is the highly cultivated and requested worldwide (Lobo \& Rojas 2020). Banana (Musa sp., family Musaceae) is the second largest produced fruit and it has a total of $16 \%$ of the total fruit production globally (Pathak et al. 2017). This species of banana weighs 25-40 
$\mathrm{kg}$ and has 15-25 combs per bunch. Each fruit measures $9-33 \mathrm{~cm}$ in length and $2.5-7.0 \mathrm{~cm}$ in diameter (Novitalia et al. 2020). The most apparent change in bananas during ripening is their peel color. The content of chlorophyll content reduced or absent in ripe fruit (Lobo \& Rojas 2020). The pulp is white, smooth, and soft textured with a sweet taste. Cavendish banana is usually eaten raw or made into delicacies such as desserts and jams (Ding et al. 2015).

Cavendish banana is highly nutritious. Banana is a highly nutritious fruit with high source of phytochemicals, unsaturated fatty acids and sterols and a medium-sized banana consists of $6 \mathrm{~g}$ of fibre (Netshiheni et al. 2019). It is very rich source of carbohydrates, minerals (potassium and calcium) as well as vitamins (A, B1, B2, and $C$ ) and provides significant amount of energy (100 $\mathrm{Cal} / 100 \mathrm{~g}$ ) to the body (Ahmed et al. 2017a). Besides that, bananas contain various antioxidant compounds such as ascorbic acid, tocopherol, beta carotene, phenolic groups, dopamine and gallocatechin (Shian \& Abdullah 2012). According to Soradech et al. (2017), it consists of high content up to $15 \%$ of vitamin C. Furthermore, there are also a high quantity of tryptophan, calcium, magnesium, and vitamin B6 in banana (Bu et al. 2020). Implementing a diet rich in fiber and potassium can control high blood pressure, hypertension, and its complications (Ajeigbe et al. 2020). Tryptophan found in banana increases serotonin synthesis and contributes to many behavioral consequences of increased serotonergic activity includes elevate mood in people ( $\mathrm{Bu}$ et al. 2020). However, the chemical composition of banana changes depending on the maturation stage. As the bananas mature and ripen, starch content decreases because approximately $80 \%$ of starch transformed to soluble sugars such as glucose, fructose and sucrose which increases the soluble sugar to $19 \%$ (Palijama et al. 2020).

Banana is highly perishable and easily deteriorates, especially after ripening. After harvesting, banana loses its water content, rendering it prone to shrivelling, weight loss, and attack by insects and decay-causing organisms (Serrano \& Rolle 2018). Palijama et al. (2017), stated that fruit maturation process causes significant changes in chemical and biochemical that cause rapid maturation and ripening. During the maturation process occurs of changes in banana that causes changes in color, texture, taste, and other chemical differences such as differences in acidity, carbohydrates, pectin, protopectin, tannin, and volatile contents (Palijama et al. 2017). According to Chen et al. (2020), dramatic softening and a short shelf life can be observed after harvesting of banana. In addition, Toma et al. (2018) mentioned that the peel colour of banana changes from green to yellow, decrease in firmness and followed by fruit softening as well as starch is converted into sugar. An average of $20-25 \%$ of the harvested banana fruits are decayed by different fungi during postharvest handling and about 1.6 million bananas are discarded daily (Idris et al. 2015).

The earlier mentioned limitations can be mitigated by proper postharvest handling of bananas and by commercialising banana into processed food products such as jam, jellies, and chips. According to the Food and Agriculture Organization of the United Nations (FAO), the banana trade reached up to 114 million tonnes in 2017, with Asia, Latin America, and Africa being the prime producers. Banana is also a cheap product, ranging from USD $0.90-1.00 / \mathrm{kg}$ (FAO 2016) in trading market. In Africa, 70 million citizens depend on banana and plantain for $25 \%$ of their energy intake. Ripe bananas undergo industrial processing to produce various products including puree, juice, and jam (Shandilya \& Siddiq 2020). In order to produce high-quality jam, the processed fruit must be ripe, have no signs of rotting, and contain sufficient pectin and acid (Dahlan 2020). Processing banana into food products eliminates food wastage, increases food diversification among consumers, improves shelf life, and provides food security. Furthermore, processing may improve market efficiency and generate employment, especially for local and small producers (Singh et al. 2018).

Jams have historically been prepared to preserve perishable fruits for consumption during the off-season. Apart from their pleasant taste, jams have a favourable nutrient profile, such as high levels of sugar, fibre, minerals, and amino acids and an absence of fat and cholesterol (Bekele et al. 2020). Jams are typically eaten on a daily basis with bread at breakfast or are used in desserts such as cakes and pastries. Jam is a semi-solid food product, obtained upon cooking of fruits or vegetables pulp with sugar, citric acid and pectin as well as other ingredients to produce a reasonable consistency (Ahmed et al. 2017b). According to Aziz et al. (2020), the heating process in jam production decreases the moisture content and sugar act as a preservative, sweetener, and gives a better consistency and texture to the end product and also helps in gel formation.

The preparation of jam is influenced by multiple factors such as the quality of the fruit and levels of pectin, sugar, pH, and total soluble solids (Aziz et al. 2020). Siddiqui et al. (2020) studied that highest amount of pectin can also be obtained from slightly under ripe bananas which increasing pectin content during development and decreasing pectin content during ripening. In jam 
production where both hydrophilic and hydrophobic interactions take place, pectin acts as a gelling agent and food hydrocolloid (Shinwari \& Rao 2020). Sugar enhances the taste, flavor, colour, and the texture of processed fruit products (Okine 2017). Okine (2017), also stated that the high amount of sugar prevents the water from the microorganisms which causes the microorganisms dehydrated and incapable to prevent spoilage of jam. A sufficient amount of acid is required for gel formation (Joardder \& Masud 2019).

In the present study, Musa cavendish banana pulps were formulated as banana jams. Response surface methodology (RSM) was employed to determine the optimal levels of sugar and pectin and volume of citric acid for jam production without compromising the physicochemical properties, sensory attributes, and shelf life of the jam. As Cavendish banana is rich in nutritional content, this approach allows the plant to be utilised to its optimum potential and benefits the growth of local industry.

\section{MATERIALS AND METHODS}

\section{CAVENDISH BANANA PULPS PREPARATION}

Cavendish bananas (Musa cavendish) were purchased from the Heromart, Sri Serdang, Selangor, Malaysia, and were washed and peeled to isolate the pulps (460 g). The pulp was sliced into small pieces and ground with water $(100 \mathrm{~mL})$ into a mash. Next, the mash was boiled at $100{ }^{\circ} \mathrm{C}$, and mixed with sugar $(175-275 \mathrm{~g})$ and pectin (3-7 g). When the mixture reached $60^{\circ} \mathrm{C}$, citric acid was added (150-234 mL, pH 3.08) and the mixture was stirred continuously until it had gelled. The jam was cooled, packed into plastic containers, and stored at either $4{ }^{\circ} \mathrm{C}$ (Tin et al. 2015) or $25^{\circ} \mathrm{C}$ in a growth chamber (GC-500, Protech, Malaysia). A total of 16 banana jam samples were prepared. The samples subsequently underwent physicochemical and modified sensory analyses (WanMohtar et al. 2018), optimised using RSM according to Sohedein et al. (2020), to determine the optimal amount of sugar and pectin and volume of citric acid for the jam formulation. All analyses were performed in triplicate.

\section{PHYSICOCHEMICAL ANALYSIS}

\section{DETERMINATION OF TOTAL TITRATABLE ACIDITY (TTA)}

Samples of jam $(6 \mathrm{~g})$ were mixed with distilled water $(50 \mathrm{~mL})$ and stirred for $2 \mathrm{~min}$ until the solution was homogenous. Phenolphthalein ( 3 drops) was then added to the solution $(10 \mathrm{~mL})$ and titrated with $\mathrm{NaOH}(0.1$ M) until a pale pink colour was obtained. The volume of titrated $\mathrm{NaOH}$ was recorded. The method used was followed from Nguyen et al. (2017):

Percentage of malic acid $(\%)=$

(volume of titrated $\mathrm{NaOH} \times 0.1 \mathrm{M} \mathrm{NaOH} \times 0.067 \times 100$ )

$$
\text { weight of samples (g) }
$$

\section{pH DETERMINATION}

The $\mathrm{pH}$ of banana jam was measured according to Ngoh Newilah et al. (2018). The pH of banana jam was measured according to $5 \mathrm{~g}$ of each produced jam samples were diluted with $50 \mathrm{~mL}$ distilled water to make a $10 \%$ solution. The $\mathrm{pH}$ values of the filtrate were measured using a digital $\mathrm{pH}$ meter (Eutech $\mathrm{pH} 700$, Singapore).

\section{COLOUR ANALYSIS}

Samples of jam were analysed for colour using a chromameter (Konica Minolta R-300) and CIELAB system (illuminator $=\mathrm{D} 65$, angle of observation $=10^{\circ}$ ). The lightness $\left(\mathrm{L}^{*}\right)$ of the jams was determined using measurements from three different areas of the samples.

\section{TOTAL SOLUBLE SOLID (BRIX) AND WATER ACTIVITY ANALYSES}

The total soluble solid content of the jams was measured using a refractometer (Abbe Atago 89553 refractometer) (Brandao et al. 2018). A small sample of jam was taken and cooled to $20^{\circ} \mathrm{C}$. The jam was then dropped into the prism and held near a source of light. The results were recorded and expressed as degree of brix ( ${ }^{\circ}$ Brix). Water activity was determined using a Unit 3TE Aqualab (Decagon Devices Inc., WA, USA). The jams were tested for $5 \mathrm{~min}$ and the results were recorded.

\section{SENSORY EVALUATION}

Sensory testing was carried out by 30 panellists from the Faculty of Food Science, Universiti Putra Malaysia, Serdang, Selangor as described previously by Nurhanan and Aishah (2012) and Wan-Mohtar et al. (2019). Samples of all 16 formulations of banana jam were spread onto bread and served to the panellists in a random order. The colour, taste, aroma, texture, appearance, and overall acceptance of the jams were evaluated using the 9-point Hedonic scale $(1=$ extremely poor, $2=$ very poor, $3=$ poor, $4=$ below fair above poor, $5=$ fair, $6=$ below good above fair, $7=$ good, $8=$ very good, $9=$ excellent). 
RESPONSE SURFACE METHODOLOGY (RSM)

Optimisation of the banana jam formulation was performed using RSM (Minitab 17 Software ; Minitab Inc., State College, PA, USA) as according to Wan-Mohtar et al. (2020) on optimized mixed-ratio chicken patty, through the central composite design (CCD) $2^{3}+$ star with a total of 16 runs. The independent variables were the amount of sugar (175-275 g), amount of pectin, (3-7 g), and volume of citric acid (150 mL - $234 \mathrm{~mL}$ ) (Table 1). The dependent variables or responses $(\mathrm{Y})$ are the physicochemical analysis $\left(\mathrm{pH}\right.$, total titratable acidity, water activity, $\left.{ }^{0} \mathrm{Brix}, \mathrm{L}^{*}\right)$ and the sensory attributes score (colour, taste, aroma, texture, and overall acceptability). The responses were fitted to a second order polynomial model (2).

TABLE 1. Optimization of the banana jams formulation through the response surface methodology (RSM). Response surface methodology was done using the central composite design (CCD) $2^{3}+$ star with a total of 16 runs. The independent variables were the amount of sugar (175-275 g), amount of pectin (3-7 g) and volume of citric acid (150-234 mL)

\begin{tabular}{|c|c|c|c|}
\hline \multirow[b]{2}{*}{ Run order } & \multicolumn{3}{|c|}{ Independent variables } \\
\hline & Amount of sugar $(\mathrm{g})$ & Amount of pectin $(\mathrm{g})$ & $\begin{array}{l}\text { Volume of citric acid } \\
\qquad(\mathrm{mL})\end{array}$ \\
\hline 1 & 225.0 & 5.00 & 119.34 \\
\hline 2 & 275.0 & 3.00 & 150.00 \\
\hline 3 & 175.0 & 3.00 & 234.00 \\
\hline 4 & 275.0 & 3.00 & 234.00 \\
\hline 5 & 275.0 & 7.00 & 234.00 \\
\hline 6 & 311.5 & 5.00 & 192.00 \\
\hline 7 & 225.0 & 8.46 & 192.00 \\
\hline 8 & 225.0 & 5.00 & 264.66 \\
\hline 9 & 225.0 & 1.54 & 192.00 \\
\hline 10 & 275.0 & 7.00 & 150.00 \\
\hline 11 & 175.0 & 7.00 & 150.00 \\
\hline 12 & 175.0 & 3.00 & 150.00 \\
\hline 13 & 175.0 & 7.00 & 234.00 \\
\hline 14 & 138.5 & 5.00 & 192.00 \\
\hline 15 & 225.0 & 5.00 & 192.00 \\
\hline 16 & 225.0 & 5.00 & 192.00 \\
\hline
\end{tabular}

$\mathrm{Y}=\mathrm{I}+\mathrm{ax}_{1}+\mathrm{bx}_{2}+\mathrm{cx}_{3}+\mathrm{dx}_{1}^{2}+\mathrm{ex}_{1} \mathrm{x}_{2}+\mathrm{fx}_{1} \mathrm{x}_{3}+\mathrm{gx}_{2}^{2}+\mathrm{hx}_{2} \mathrm{x}_{3}$ $+\mathrm{ix}_{3}^{2}+\varepsilon$

where $\mathrm{Y}$ is the measured response; $\mathrm{I}$ is a constant; $\mathrm{a}, \mathrm{b}$, and $c$ are linear coefficients for the first order; $d, g$, and $i$ are square coefficients; $\mathrm{e}, \mathrm{f}$, and $\mathrm{h}$ are interaction coefficients; $\mathrm{x}_{1}, \mathrm{x}_{2}, \mathrm{x}_{3}, \mathrm{x}_{1}^{2}$, and $\varepsilon$ is the error.

\section{STATISTICAL ANALYSIS}

Statistical analyses were conducted using the Minitab 17 software. One-way analysis of variance (ANOVA) with 
Tukey's multiple comparisons were performed. The values were expressed as a mean \pm standard deviation to determine the significant differences among means for all testing at $p$-value of 1 at $\mathrm{a}=0.05$.

\section{RESULTS AND DISCUSSION}

\section{PHYSICOCHEMICAL ANALYSES TOTAL SOLUBLE SOLID $\left({ }^{\circ}\right.$ BRIX) AND WATER ACTIVITY}

In Table 1, the results show that different amounts of sugar added to the jams affected the water activity and ${ }^{\circ}$ Brix while the amount of pectin and volume of citric acid remained unaffected in all jams. Sugar promotes hydrophobic interactions between pectin chains by decreasing water activity (Shinwari \& Rao 2020). Similarly, Kanwal et al. (2017) stated that different treatments can affect the water activity in guava jam. No interactions were found between the independent variables and the water activity and ${ }^{\circ}$ Brix.

\section{COLOUR ANALYSIS}

According to Figure 6, Lightness ( $\mathrm{L}^{*}$ ) was shown not to be influenced by the amount of sugar and pectin and volume of citric acid added in the banana jams. However, the interaction between the amount of pectin and volume of citric acid used was found to influence the $\mathrm{L}^{*}$ of the jams can be seen in Figure 6. Abid et al. (2018) reported that pectin concentration influences colour of pomegranate jam. Degradation occurred for anthocyanin-binding systems and the red colour of all samples tended to disappear mainly due to anthocyanins thermal degradation and pectin esterifications during heating process (Fernandes et al. 2020). Aksay et al. (2018) showed that citric acid played a role in the changes in $\mathrm{L}^{*}$ in banana jams.

\section{pH ANALYSIS}

Based on Figure 6, results from the $\mathrm{pH}$ analysis showed that the volume of citric acid had a linear effect on the $\mathrm{pH}$ of the banana jams. The interaction between the amount of sugar and volume of citric acid was shown to influence the $\mathrm{pH}$ of the jams also shown in Figure 6. Ngoh Newilah et al. (2018) reported that as the quantity of pulp increases, the $\mathrm{pH}$ of jam produced using CARBAP K74 fruit harvested either from Njombé or Bansoa increases due to the low titratable acidity of the CARBAP K74 pulp. Kanwal et al. (2017) stated that intervals $\mathrm{pH}$ decreases due to increase in acidity during storage which leads to breakdown of pectin during storage and ascorbic acid is also decreased in storage and forms dehydro ascorbic acid from oxidation of ascorbic acid.
TOTAL TITRATABLE ACID (TTA) ANALYSIS

Figure 1 shows the volume of citric acid had a linear effect on TTA, while interactions between sugar and acid and between pectin and acid were found to have influenced the TTA of the banana jams. Kanwal et al. (2017) stated that the interaction of pectin and acid can be explained due to the breakdown of pectin in to pectinic acid during preparation of jam. Thus, the acidity value increases.

\section{FITTING THE MODEL WITH RESPONSE SURFACE METHODOLOGY (RSM)}

Based on the statistical analysis, the independent variables that showed no significant influence $(p>0.05)$ on the physicochemical properties were eliminated to obtain the model. $\mathrm{R}^{2}$ values indicated the accuracy between the predicted values and experimental results for the measured response. All physicochemical analyses showed low $\mathrm{R}^{2}$ values, indicating that the variance in sugar and pectin content and volume of citric acid contribute low variance with respect to water activity $\left(\mathrm{R}^{2}=33.74 \%\right)$, ${ }^{\circ}$ Brix $\left(\mathrm{R}^{2}=32.64 \%\right), \mathrm{L}^{*}\left(\mathrm{R}^{2}=48.47 \%\right)$, and $\mathrm{pH}\left(\mathrm{R}^{2}=\right.$ $63.05 \%)$ for all banana jams except for TTA $\left(\mathrm{R}^{2}=77.50\right.$ $\%$ ). Therefore, only TTA was selected for the identification of the optimum range area as follows:

$$
\begin{aligned}
Y_{1}= & -1.308+0.003118 S+0.2784 P+0.00420 A \\
& -0.000638 S P-0.000640 P A
\end{aligned}
$$

where $\mathrm{Y}_{1}$ is TTA; $\mathrm{S}$ is $\boldsymbol{B}$ coefficient of sugar; $\mathrm{A}$ is $\boldsymbol{B}$ coefficient citric acid; SP is $\boldsymbol{B}$ coefficient of the interaction between the amount of sugar and pectin; and PA is $\boldsymbol{B}$ coefficient of the interaction between the amount of pectin and volume of citric acid. Nonetheless, different variables should be investigated or added to the experiments to obtain higher $\mathrm{R}^{2}$ values. The inclusion of additional axial points is necessary to adjust the model to a larger order (second degree) (Silva et al. 2012). Lee et al. (2006) studied the effects on the quantity of pulp and sugar and the cooking time to improve the $\mathrm{R}^{2}$ for all responses. Overall, the optimal formulation based on the ideal physicochemical properties of the banana jam was $297.52 \mathrm{~g}$ of sugar $4.23 \mathrm{~g}$ of pectin and $264.66 \mathrm{~mL}$ of citric acid (water activity $=0.80 \mathrm{a}_{\mathrm{w}}$, target $65^{\circ} \mathrm{Brix}, \mathrm{pH} 3.35$ TTA $=0.39 \%$, and maximum L*). Khan et al. (2020) showed that jams consists of total soluble substances of about $68.5 \%$ and at least $45 \%$ of fruit pulp. Addition of pectin and acids is critical to meet a minimum pectin requirement of $1 \%$ and $\mathrm{pH} 3.0$, as gel network is formed by pectin with specific TSS and $\mathrm{pH}$ (Shinwari \& Rao 2018). The U.S. Food and Drug Administration (FDA) has suggested a water activity $\left(\mathrm{a}_{\mathrm{w}}\right)<0.85 \mathrm{aw}$ in a finished food product (Garces-Vega et al. 2019). 


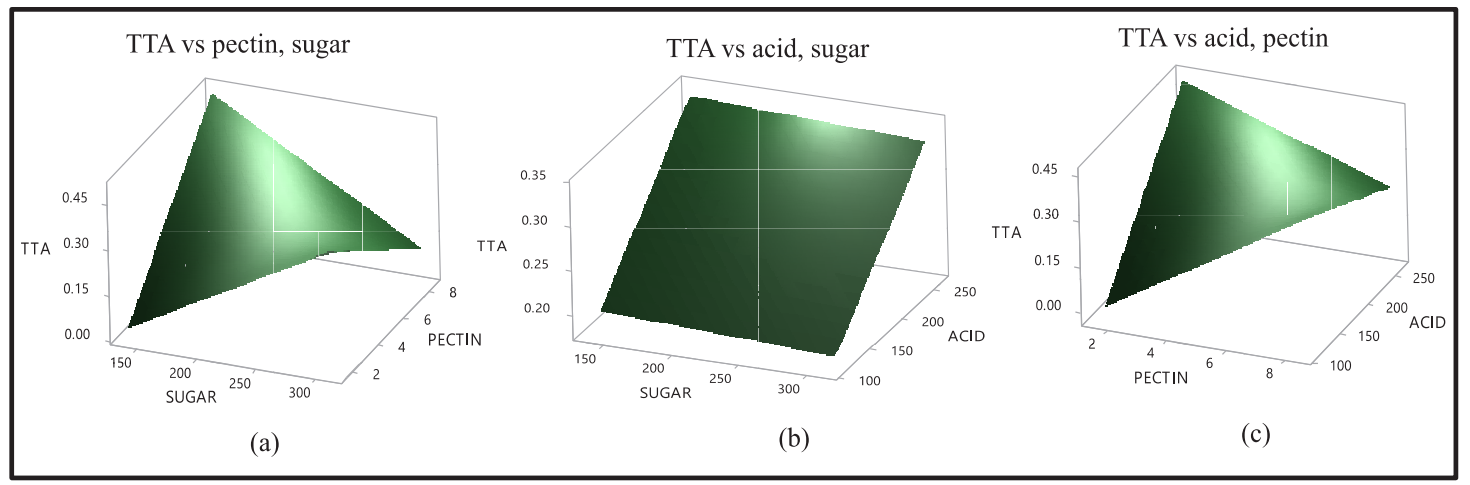

FIGURE 1. Response surface plot for the effect of (a) quantity of sugar and pectin, (b) quantity of sugar and citric acid, and (c) quantity of pectin and citric acid on total titratable acidity (TTA) of banana jam. The banana jams with different amount of sugar (175-275 g), pectin (3-7 g) and concentration of citric acid (150$234 \mathrm{~mL}$ ) were treated with phenolphthalein and titrated with sodium hydroxide

Figure 1 shows the surface plot of the effect of sugar and pectin amount and volume of citric acid on the TTA in banana jam. A high sugar content (300 g) was found to increase the TTA $(0.35 \%)$ with a high volume of citric acid $(250 \mathrm{~mL})$ (Figure 1(b)). Commercial strawberry jam recorded highest total titrable acidity $(0.68 \pm 0.00)$ in jam with the highest total soluble solids $(51.00 \pm 0.00)$ influenced by the amount sugar content (Makanjuola \& Alokun 2019). Similarly, Napio (2018) found that the highest amount of sugar $(57.70 \mathrm{~g})$ in shea fruit jam had the highest TTA value $(0.31 \pm 0.07 \%)$. Pectin $(8 \mathrm{~g})$ and citric acid $(250 \mathrm{~mL})$ were found to reduce the TTA $(0.30 \%)$ in banana jams (Figure 1(c)). This result can be attributed to the interaction of $\mathrm{H}^{+}$ions with pectin networks (Evageliou et al. 2000).

\section{SENSORY EVALUATION}

Sensory evaluation on the colour, taste, aroma, and overall acceptability on the banana jams showed that the no. 16 banana jam was the most preferred by the 30 panellists. Jam no. 4 had the best texture (Figure 2), while jam no. 14 (138.5 g sugar, $5 \mathrm{~g}$ pectin, and $192 \mathrm{~mL}$ citric acid) was the jam least preferred by the panellists and had the lowest amount of sugar, which caused the jam to appear runny due to reduced gelation and light in colour. Similarly, Ahmed et al. (2016), reported that low level of sugar causes a decrease in the caramelised brown colour of sapodilla jam.

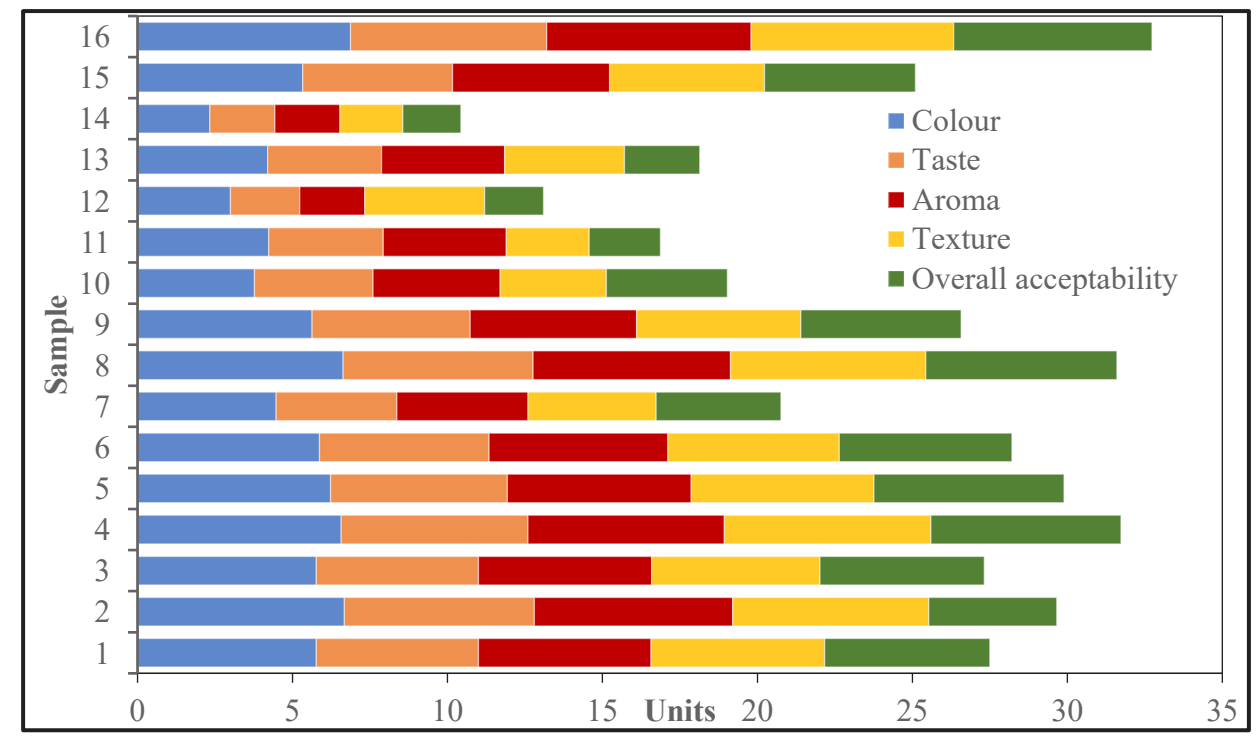

FIGURE 2. Sensory evaluation on the texture on banana jams. The thirty panellists were chosen from local Malaysians from the Food Science Department, Universiti Putra Malaysia, Serdang, Selangor, Malaysia. A total of sixteen different formulated banana jams were spread on breads to be given to the panellists for sensory evaluation 
Statistical analysis on the colour $\left(\mathrm{R}^{2}=70.86 \%\right)$, taste $\left(\mathrm{R}^{2}=71.78 \%\right)$, aroma $\left(\mathrm{R}^{2}=70.50 \%\right)$, texture $\left(\mathrm{R}^{2}=80.10\right.$ $\%)$ and overall acceptability $\left(\mathrm{R}^{2}=73.25 \%\right)$ showed that the amount of sugar had a linear and quadratic effects on all the sensory attributes of the banana jams. Conversely, the amount of pectin used had only linear and quadratic effects on the texture of the banana jams, while the volume of citric acid had a linear and quadratic effect on both the texture and overall acceptability of the banana jams.

\section{FITTING THE MODEL FROM THE RESPONSE SURFACE} METHODOLOGY (RSM)

Sensory analysis results were fitted to a model to determine the effects of the amount of sugar and pectin and volume of citric acid on the colour $\left(\mathrm{Y}_{2}\right)$, taste $\left(\mathrm{Y}_{3}\right)$, aroma $\left(\mathrm{Y}_{4}\right)$, texture $\left(\mathrm{Y}_{5}\right)$, and overall acceptability $\left(\mathrm{Y}_{6}\right)$ of the banana jams $((4)-(8)) . \mathrm{R}^{2}$ indicated that the predicted values and experimental results for the colour $\left(\mathrm{R}^{2}=\right.$ $70.86 \%)$, taste $\left(\mathrm{R}^{2}=71.78 \%\right)$, aroma $\left(\mathrm{R}^{2}=70.50 \%\right)$, texture $\left(\mathrm{R}^{2}=80.10 \%\right)$, and overall acceptability $\left(\mathrm{R}^{2}=\right.$ $73.25 \%$ ) were comparable. The quadratic and interaction terms for pectin and the volume of citric acid were removed from the final model as they did not significantly affect the sensory attributes ( $p \geq 0.05$ ). The optimal formulation based on the ideal sensory properties of banana jam was predicted to be achieved with the addition of $262.571 \mathrm{~g}$ of sugar, $1.54 \mathrm{~g}$ of pectin, and $264.66 \mathrm{~mL}$ of citric acid.

$$
\begin{aligned}
& Y_{2}=-10.99+0.1208 \mathrm{~S}-0.200 \mathrm{P}+0.01122 \mathrm{~A}-0.000230 \mathrm{SS}( \\
& Y_{3}=-10.36+0.1092 \mathrm{~S}-0.172 \mathrm{P}+0.01071 \mathrm{~A}-0.000202 \mathrm{SS} \\
& Y_{4}=-11.40+0.1182 \mathrm{~S}-0.158 \mathrm{P}+0.01130 \mathrm{~A}-0.000220 \mathrm{SS} \\
& Y_{5}=-11.00+0.1217 \mathrm{~S}-0.3022 \mathrm{P}+0.01154 \mathrm{~A}-0.000231 \mathrm{SS}( \\
& Y_{6}=-13.97+0.1281 \mathrm{~S}-0.167 \mathrm{P}+0.01568 \mathrm{~A}-0.000238 \mathrm{SS}
\end{aligned}
$$

where $\mathrm{Y}_{2}$ is colour; $\mathrm{Y}_{3}$ is taste; $\mathrm{Y}_{4}$ is aroma; $\mathrm{Y}_{5}$ is texture; $\mathrm{Y}_{6}$ is overall acceptability; $\mathrm{S}$ is the amount of sugar; $\mathrm{A}$ is volume of citric acid; $\mathrm{SS}$ is the interaction between the amount of sugar.

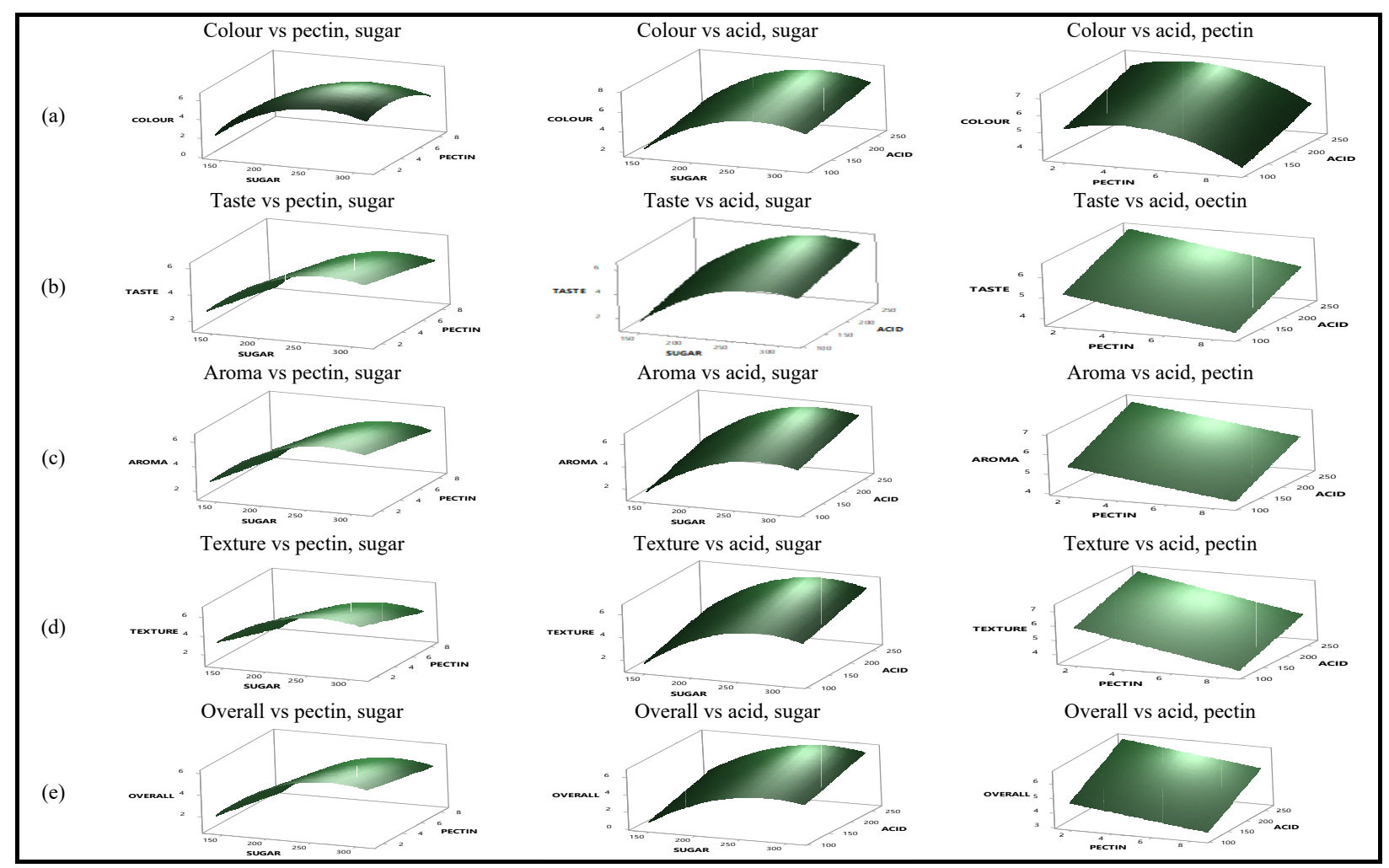

FIGURE 3. Surface plots for the colour (a), taste (b), aroma (c), texture (d) and overall acceptance (e) of the banana jams against the amount of sugar (175-275 g) and pectin (3-7 g) and concentration of acid (150-234 mL) 
Figure 3 shows the surface plot for the effect of the amount of sugar and pectin and volume of citric acid on the sensory quality of the banana jams. Sugar was found to influence all sensory attributes of the banana jam. Flavour and aroma enhancement in the banana jam with incremental increase in sugar usage were attributable to the occurrence of the Maillard reaction during the cooking process. The Maillard reaction is a browning reaction that takes place when reducing sugars react with amino acids to form Maillard reaction products (MRPs) (Teodorowicz et al. 2017). The increase in sugar levels triggered an increased Maillard reaction in the banana jam, thus enhancing its flavour and aroma. Besides flavor, colour and texture, the quality of jam is evaluated by the aroma as the sensory indicator (Zhang et al. 2020). Esters are the major group of volatile aroma compounds in banana includes alcohols and aldehydes (Shivashankara 2016). A previous study reported on the various sensory profiles of pineapple jams using different formulations of sugar, pectin, and citric acid (Bierhals et al. 2011).

Sugar was also observed to affect the texture of the banana jam. The banana jam samples with lower amounts of sugar had a runny appearance. Rýdlová et al. (2020) reported that parameter $\left(L^{*}\right)$ of prepared strawberry spreads shows that the addition of sugar significantly reduces product lightness $(p=0.001)$. In addition, samples containing $40-50 \%$ of strawberry puree and $30-40 \%$ of sugar achieved the highest gel stiffness and samples without strawberry puree and low sugar content (10-20 \%) showed low gel stiffness (Rýdlová et al. 2020). Sucrose is an appropriate sugar for jam production as it has less potential for re-crystallisation compared to glucose (Ahmed et al. 2016). Akesowan and Choonhahirun (2019) indicated that the use of sucrose in a jam could affect the texture of konjac gel due to a bulking effect. Sucrose competes with xanthan for available water molecules, affecting the structural rigidity. However, the researchers discovered that the substitution of erythritol-sucralose (ES) in konjac gel did not have any effect on its texture.

Subsequently, Quintana et al. (2018) reported that sugar concentration and type of hydrocolloid had an effect on the texture of soursop jam. Furthermore, sucrose forms rigid gels to obtain a desirable texture, and higher amounts of sugar improve the viscosity of jam (Ahmed et al. 2016). Furthermore, Ahmed et al. (2016) also reported that high sugar concentrations result in the most preferable colour, texture, taste, flavour, and overall acceptability for sapodilla jam.

The amount of pectin and volume of citric acid were also found to improve the texture of the banana jam.
Siddiqui et al. (2015) reported on the increased viscosity of sapodilla jam with a gradual increase in amount of pectin.

According to the FAO (2016), a pH of $3.0-3.3$ is preferred for proper gelation of a jam. Pectin is the major factor affecting the consistency and hardness of gel (Banaś et al. 2018). Pectin strands carries negative electric charges and can be neutralised by the addition of acid, which decreases the $\mathrm{pH}$ of the jam mixture; hence, the pectin strands form a network which can set the jam (Bekele et al. 2020). Barbieri et al. (2018) stated that the gelation of jam occurs from the high temperature during cooking process and process of gelation of high methoxyl pectin. Jam can be observed as good quality by its vivid color, maintain the original fruit's flavour, intermediate consistency and texture; however, these characteristics of jam may be varied during storage (Brandão et al. 2018).

\section{SHELF LIFE STUDY}

Anggraini et al. (2019) stated that the higher the temperature storage, the faster the damage of the product will be. Ascorbic acid decreases due to oxidation and enzymatic catalytic reaction within the mass of jam during storage (Khan et al. 2020). The banana jams stored at $25^{\circ} \mathrm{C}$ had developed mould by day 7 (Figure 4(a)). However, some banana jams developed mould in a shorter time due to differences in the amount of sugar and acidity of the jams. Sugar present in jam reduces its water activity resulting in longer shelf life (Shinwari \& Rao 2018). Makanjuola and Alokun (2019) stated that the importance of high acidity in food products shows that food product can be stored before spoilage or deterioration takes place. Similarly, Tifani et al. (2018) reported that increasing the acidity of durian jam enhanced its shelf life as it protected the jam from microorganisms.

In contrast, the banana jams stored at $4{ }^{\circ} \mathrm{C}$ remained in good condition with no mould up until day 14 (Figure 5(a)). At $4{ }^{\circ} \mathrm{C}$, lower water activity and higher total soluble solids (sugar content) in the banana jams contributed to prolonging the shelf life of the jams. Water activity (Aw) is critical to ensure for food safety by reducing it for increased shelf life and reduced microbial activity (Lopez-Malo \& Alzamora 2015). In addition to enhancing flavour and texture, sugar acts as preservative and aids in inhibiting microbial growth (Benmeziane et al. 2018). A high level of sugar is usually associated with low water activity and moisture content, making the environment unsuitable for microbial growth (Benmeziane et al. 2018). Sugars bind water molecules, leading to a reduction in water activity (Kanwal et al. 2017). Similarly, Martinsen et al. (2020) reported that the stability of anthocyanins of jam was higher at the lowest storage temperature $\left(4^{\circ} \mathrm{C}\right)$ compared to at room temperature. 


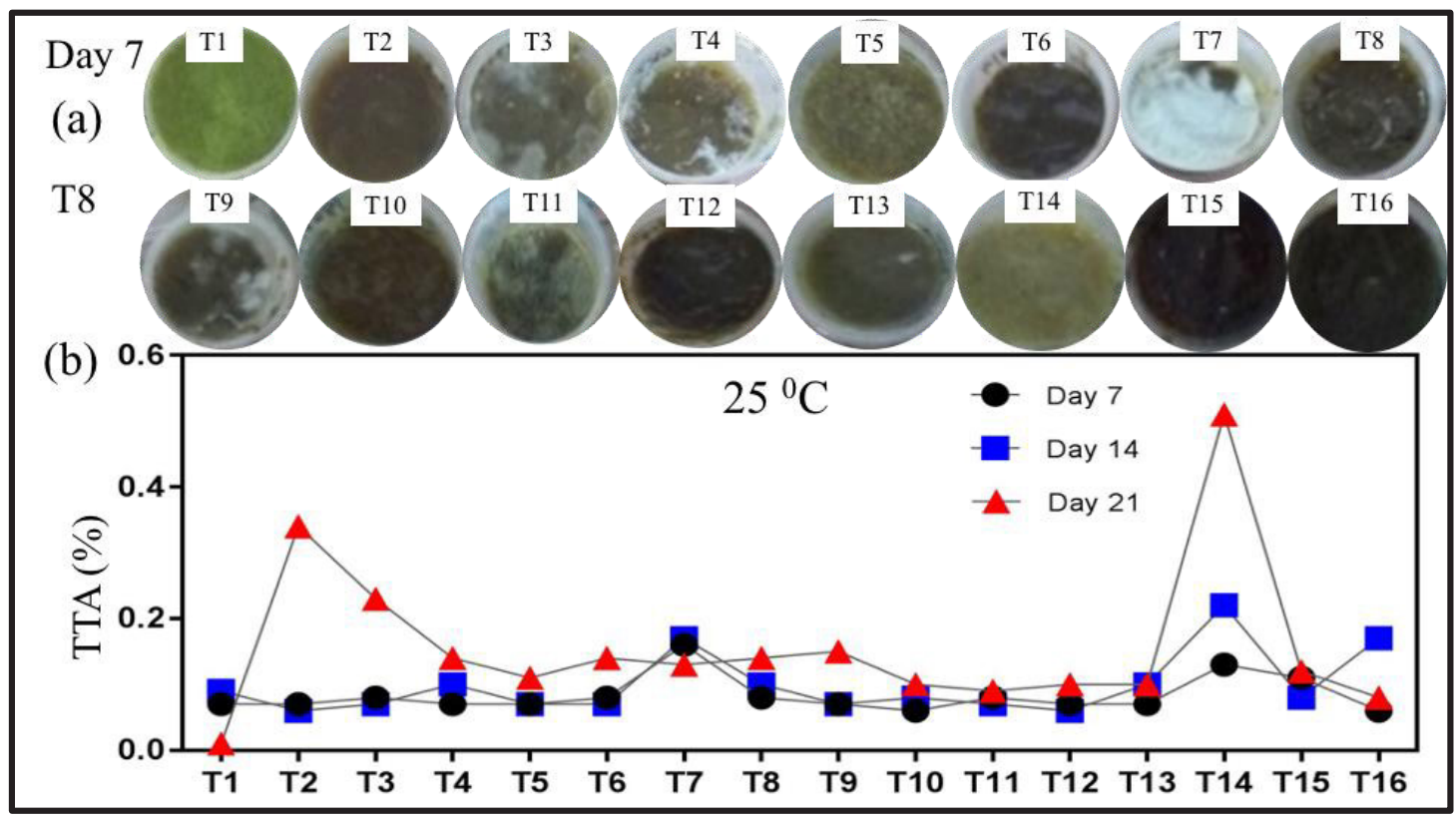

FIGURE 4. Condition of the banana jams stored at $25{ }^{\circ} \mathrm{C}$ up until day 7 (a) and the change in the total titratable acid (TTA) (\%) in the banana jams at day 7, 14 and 21. The error bars were too small to be represented in the graph

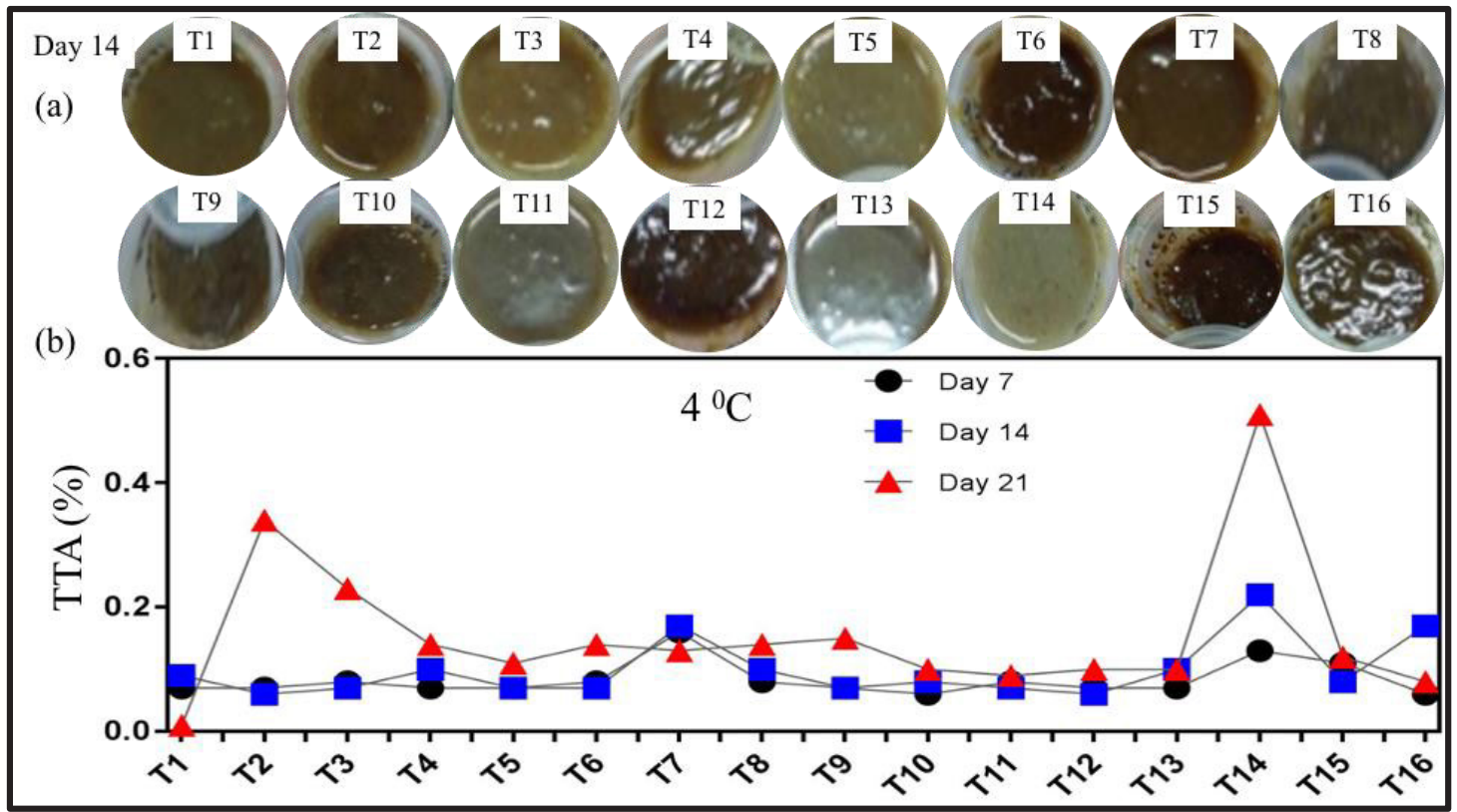

FIGURE 5. Condition of the banana jams stored at $4{ }^{\circ} \mathrm{C}$ up until day 14 (a) and the change in the total titratable acid (TTA) (\%) in the banana jams at day 7, 14 and 21. The error bars were too small to be represented in the graph 
The $\mathrm{pH}$ and TTA of the banana jams showed that there were no significant differences $(p \geq 0.05)$ in the banana jams stored at both temperatures (Figure 4(b) and 5(b)). This finding may be attributable to a narrow range of sugar and pectin quantity and volume of citric acid used in making the banana jams. $\mathrm{pH}$ and TTA are related to acidity, which is important in determining the quality of a food product. According to Asema and Parveen (2018), the adequate level of acidity is important for gel formation. If there is too little acid, the gel will never set and if there is too much acid, the gel will lose liquid. Other than that, the acidity of a food product represents the stability and shelf life of that product (Kanwal et al. 2017). Similarly, Brandão et al. (2018) observed pH stability in cerrado fruit jam during storage. Conversely, Shah et al. (2015) reported that decreasing trend in $\mathrm{pH}$ of apple and olive jam during storage might be due the hydrolysis of pectic bodies and formation of acidic compound during degradation of sugar contents. Ngoh Newilah et al. (2018) observed a significant increase in TTA in jams stored at 25 ${ }^{\circ} \mathrm{C}$ as the storage period increased, due to an increase in the concentration of weakly ionised acids and their salts. Overall, the optimal formulation of banana jam for the best quality and safety was found to be $281.79 \mathrm{~g}$ of sugar, $4.13 \mathrm{~g}$ of pectin, and $264.66 \mathrm{~mL}$ of citric acid (Figure 6).

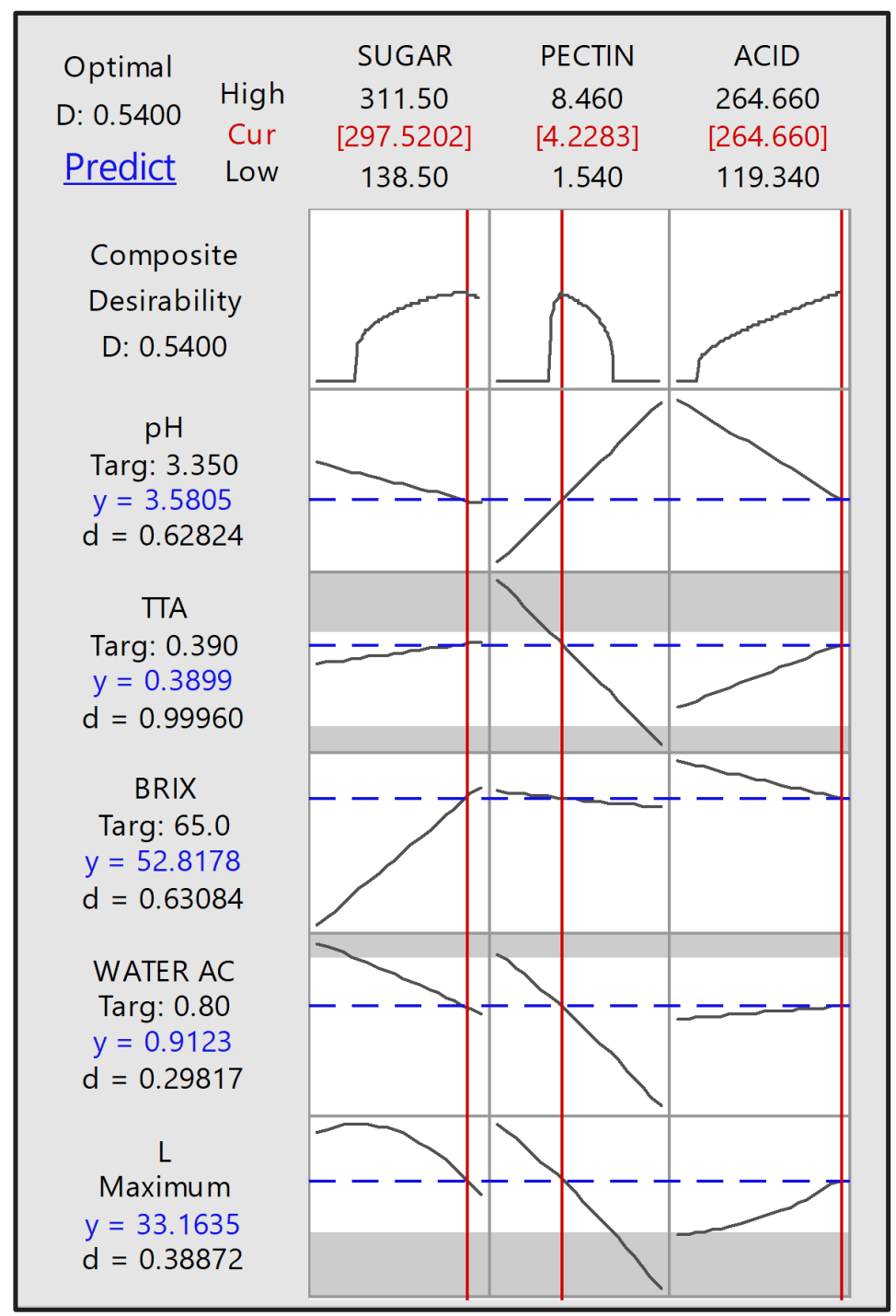

FIGURE 6. Predicted optimal formulation for the preparation of the banana jam with the best quality was $281.79 \mathrm{~g}$ of sugar, $4.13 \mathrm{~g}$ of pectin and 264.66 $\mathrm{mL}$ of citric acid with water activity $=0.80 \mathrm{aw},{ }^{\circ} \mathrm{Brix}=65 \%, \mathrm{pH}=3.35$, TTA $=0.39 \%$ and maximum $\mathrm{L}^{*}$ 


\section{CONCLUSION}

Physicochemical analyses showed that the amount of sugar and pectin and the volume of citric acid affected the TTA and $\mathrm{pH}$ of banana jam. Water activity and ${ }^{\circ}$ Brix were only influenced by the amount of sugar added to the jam. Lightness $\left(\mathrm{L}^{*}\right)$ was affected by the amount of pectin and volume of citric acid. Subsequent sensory analyses showed that the amount of sugar affected the colour, aroma, taste, texture, and overall acceptability of the banana jams. Furthermore, banana jams stored at $4{ }^{\circ} \mathrm{C}$ showed higher stability and better shelf life due to high total soluble solids (sugar content), which lower the water activity and moisture content compared with those stored at ambient temperature $\left(25^{\circ} \mathrm{C}\right)$. Overall, the predicted optimal formulation for the preparation of banana jam with the best quality (water activity $=0.80 \mathrm{aw},{ }^{\circ} \mathrm{Brix}=$ $65 \%, \mathrm{pH}=3.35, \mathrm{TTA}=0.39 \%$, maximum $\mathrm{L}^{*}$ ) and safety was $281.79 \mathrm{~g}$ of sugar, $4.13 \mathrm{~g}$ of pectin, and $264.66 \mathrm{~mL}$ of citric acid. Taken together, these findings support the precommercialisation potential of Musa cavendish banana using the most efficient formulation for jam preparation.

\section{ACKNOWLEDGEMENTS}

We would like to thank the Universiti Putra Malaysia under research grant Putra Young Initiative (IPM/2017/9552400) and Malaysia Ministry of Education (MOE) for providing research grant under Fundamental Research Grant Scheme (FRGS/1/2018/TK03/UPM/02/7) awarded to Dr Sarina and FRGS: FP066-2018A to Dr Wan-Mohtar.

\section{REFERENCES}

Abid, M., Yaich, H., Hidouri, H., Attia, H. \& Ayadi, M. 2018. Effect of substituted gelling agents from pomegranate peel on colour, textural and sensory properties of pomegranate jam. Food Chemistry 239: 1047-1054.

Ahmed, A., Ali, S.W., Rehman, K.U., Manzoor, S., Ayub, S.R. \& Ilyas, M. 2016. Influence of sugar concentration on physicochemical properties and sensory attributes of sapodilla jam. PeerJ PrePrints 4: e1777v1.

Ahmed, I., Khan, M.U., Qazi, I.M., Ullah, S.U., Khan, A. \& Jamal, S. 2017a. Development and quality evaluation of banana mushroom blended jam. Biological Sciences-PJSIR 60(1): 11-18.

Ahmed, I., Ullah, S., Khan, A., Ayub, M., Shamrez, B. \& Khan, M.U. 2017b. Influence of carrot pulp fortified with different concentrations of apple pulp on blended jam. Biological Sciences-PJSIR 60(2): 92-101.

Ajeigbe, O.F., Ademosun, A.O. \& Oboh, G. 2020. Relieving the tension in hypertension: Food-drug interactions and antihypertensive mechanisms of food bioactive compounds. Journal of Food Biochemistry 45(3): e13317.
Akesowan, A. \& Choonhahirun, A. 2019. Optimization of sugar-free konjac gel texture containing erythritol-sucralose sweetener for producing healthy jam. Food Research 3(3): 241-248.

Aksay, S., Tokbaş, H., Arslan, R. \& Çınar, F. 2018. Some physicochemical properties of the whole fruit mandarin jam. Turkish Journal of Agriculture-Food Science and Technology 6(5): 632-635.

Anggraini, A., Sayuti, K. \& Yenrina, R. 2019. Accelerated shelf life test (ASLT) method with Arrhenius approach for shelf life estimation of sugar palm fuit jam with addition of Asian Melastome (Melastoma malabathricum, L.) on jar packaging and pouch. Journal of Applied Agricultural Science and Technology 3(2): 268-279.

Asema, S.U.K. \& Parveen, N. 2018. Study of heavy metal content by AAS in a variety of flavours of jam samples and its physicochemical characterization. International Journal of Scientific Research in Science, Engineering and Technology 4: 1259-1261.

Aziz, Y., Zeb, A. \& Uzair, M. 2020. Preparation of value-added guava jam with addition of papaya. Pure and Applied Biology 9(1): 554-564.

Banaś, A., Korus, A. \& Korus, J. 2018. Texture, color, and sensory features of low-sugar gooseberry jams enriched with plant ingredients with prohealth properties. Journal of Food Quality 2018: Article ID. 1646894.

Barbieri, S.F., de Oliveira Petkowicz, C.L., de Godoy, R.C.B., de Azeredo, H.C.M., Franco, C.R.C. \& Silveira, J.L.M. 2018. Pulp and jam of gabiroba (Campomanesia xanthocarpa Berg): Characterization and rheological properties. Food Chemistry 263: 292-299.

Bekele, M., Satheesh, N. \& Jemal, S. 2020. Screening of Ethiopian mango cultivars for suitability for preparing jam and determination of pectin, sugar, and acid effects on physico-chemical and sensory properties of mango jam. Scientific African 7: e00277.

Benmeziane, F., Djermoune-Arkoub, L., Boudraa, A. \& Bellaagoune, S. 2018. Physicochemical characteristics and phytochemical content of jam made from melon (Cucumis melo). International Food Research Journal 25(1): 133-141.

Bierhals, V.S., Chiumarelli, M. \& Hubinger, M.D. 2011. Effect of cassava starch coating on quality and shelf life of freshcut pineapple (Ananas comosus L. Merril cv "Perola"). Journal of Food Science 76(1): E62-E72.

Brandão, T., Do Carmo, E., Elias, H., De Carvalho, E., Borges, S. \& Martins, G. 2018. Physicochemical and microbiological quality of dietetic functional mixed cerrado fruit jam during storage. The Scientific World Journal 2018: Article ID 2878215.

Bu, L., Lai, Y., Deng, Y., Xiong, C., Li, F., Li, L., Suzuki, K., Ma, S. \& Liu, C. 2020. Negative mood is associated with diet and dietary antioxidants in university students during the menstrual cycle: A cross-sectional study from Guangzhou, China. Antioxidants 9(1): 23.

Chen, L., Zhao, X., Wu, J.E., He, Y. \& Yang, H. 2020. Metabolic analysis of salicylic acid-induced chilling tolerance of 
banana using NMR. Food Research International 128: 108796.

Dahlan, D.N.A. 2020. Analysis of beta-carotene content differences in cempedak jam using traditional and carbides fruit ripening methods. Food Science and Technology Journal (Foodscitech) 2(2): 35-40.

Ding, P., Rosli, M.F. \& Mahassan, N.A. 2015. UV-C irradiation affects quality, antioxidant compounds and activity of Musa AAA Berangan. Sains Malaysiana 44(8): 1095-1101.

Evageliou, V., Richardson, R. \& Morris, E. 2000. Effect of pH, sugar type and thermal annealing on high-methoxy pectin gels. Carbohydrate Polymers 42(3): 245-259.

FAO. 2016. Banana Facts and Figures. Rome: Food and Agriculture Organization of the United Nations (FAO).

Fernandes, A., Brandão, E., Raposo, F., Maricato, É., Oliveira, J., Mateus, N., Coimbra, M.A. \& de Freitas, V. 2020. Impact of grape pectic polysaccharides on anthocyanins thermostability. Carbohydrate Polymers 239: 116240.

Garces-Vega, F.J., Ryser, E.T. \& Marks, B.P. 2019. Relationships of water activity and moisture content to the thermal inactivation kinetics of Salmonella in low-moisture foods. Journal of Food Protection 82(6): 963-970.

Idris, F.M., Ibrahim, A.M. \& Forsido, S.F. 2015. Essential oils to control Colletotrichum musae in vitro and in vivo on banana fruits. American-Eurasian Journal of Agricultural and Environmental Science 15(3): 291-302.

Joardder, M.U. \& Masud, M.H. 2019. Challenges and mistakes in food preservation. In Food Preservation in Developing Countries: Challenges and Solutions, Cham: Springer. pp. 175-198.

Kanwal, N., Randhawa, M.A. \& Iqbal, Z. 2017. Influence of processing methods and storage on physico-chemical and antioxidant properties of guava jam. International Food Research Journal 24(5): 2017-2027.

Khan, A., Shah, F.N., Zeb, Q., Zeeshan, M., Iqbal, H. \& Noor, H. 2020. Preparation and development of fig fruit jam blended with different level of apple pulp. Biological SciencesPJSIR 63(2): 105-112.

Lee, W., Yusof, S., Hamid, N.S.A. \& Baharin, B. 2006. Optimizing conditions for enzymatic clarification of banana juice using response surface methodology (RSM). Journal of Food Engineering 73(1): 55-63.

Lobo, M.G. \& Rojas, F.J.F. 2020. Biology and postharvest physiology of banana. In Handbook of Banana Production, Postharvest Science, Processing Technology, and Nutrition, New Jersey: John Wiley \& Sons, Inc. pp. 19-44.

Lopez-Malo, A. \& Alzamora, S. 2015. Water activity and microorganism control: Past and future. In Water Stress in Biological, Chemical, Pharmacentical and Food Systems, New York: Springer pp. 245-262.

Makanjuola, O.M. \& Alokun, O.A. 2019. Microbial and physicochemical properties of date jam with inclusion of apple and orange fruits. International Journal of Food Science and Nutrition 4(3): 102-106.
Martinsen, B.K., Aaby, K. \& Skrede, G. 2020. Effect of temperature on stability of anthocyanins, ascorbic acid and color in strawberry and raspberry jams. Food Chemistry 316: 126297.

Napio, R. 2018. Physico-chemical, nutritional, microbial and organoleptic properties of jam and juice processed from shea fruit pulp. PhD Thesis. Kampala: Makerere University (Unpublished).

Netshiheni, R.K., Omolola, A.O., Anyasi, T.A., Jideani \& A.I. 2019. Banana bioactives: Absorption, utilisation and health benefits. In Banana Nutrition-Function and Processing Kinetics. London: IntechOpen. https://www.intechopen.com/ books/banana-nutrition-function-and-processing-kinetics.

Ngoh Newilah, G.B., Njapndounke, B., Tembe Tembe, J., Nkouandou, M., Ngombi Ngombi, E., Kendine, V.C., Manjia, N.S.U. \& Zambou, N.F. 2018. Optimization of process conditions for jam production from plantain-like hybrid (CARBAP K74) grown in two agro-ecological zones of Cameroon. International Journal of Agricultural Policy and Research 6(4): 50-63.

Nguyen, H., Maneepong, S. \& Suraninpong, P. 2017. Effects of potassium, calcium and magnesium ratios in soil on their uptake and fruit quality of pummelo. Journal of Agricultural Science 9(12): 110-121.

Novitalia, N., Novenda, I.L. \& Pujiastuti, P. 2020. Divesty of banana varieties (Musa sp.) in Pasrujambe district, Lumajang regency. Jurnal Pendidikan IPA 3(1): 7-15.

Nurhanan, A. \& Aishah, M. 2012. Effect of partial replacement of wheat flour with oyster mushroom (Pleurotus sajor-caju) powder on nutritional composition and sensory properties of butter biscuit. Sains Malaysiana 41(12): 1565-1570.

Okine, U.N.K. 2017. Formulation of pawpaw and pineapple jams and assessment of sensory quality by fuzzy modeling. PhD Thesis. Kumasi: Kwame Nkrumah University of Science and Technology (Unpublished).

Palijama, S., Singkery, M., Breemer, R. \& Polnaya, F. 2020. Isolation and characteristics of Musa troglodytarum L. starch at different maturity stage. Journal of Physics: Conference Series pp. 012015.

Palijama, S., Tawali, A.B., Djide, N. \& Salengke, S. 2017. Physico-chemical characteristics of tongka langit banana (Musa troglodytarum L.) at different maturity stages. International Journal of Sciences: Basic and Applied Research 31: 50-57.

Pathak, P.D., Mandavgane, S.A. \& Kulkarni, B.D. 2017. Fruit peel waste: Characterization and its potential uses. Current Science 113(3): 444-454.

Quintana, S.E., Pardo, A., Castellón, S., González-Cuello, R. \& García-Zapateiro, L. 2018. Effect of blend of hydrocolloids and sugar concentration on the viscoelastic properties of soursop (Annona muricata) jam. Contemporary Engineering Sciences 11(17): 815 -824. 
Rýdlová, L., Škorpilová, T., Juhászová, G. \& Rajchl, A. 2020. Assessment of possibilities of strawberry jam reformulation. Potravinarstvo Slovak Journal of Food Sciences 14: 554-561.

Serrano, E.P. \& Rolle, R. 2018. Post-Harvest Management of Banana for Quality and Safety Assurance. Rome: Food and Agriculture Organization of the United Nations.

Shah, W., Khan, A., Zeb, A., Khan, M.A., Shah, F.N., Amin, N., Ayub, M., Wahab, S., Muhammad, A. \& Khan, S.H. 2015. Quality evaluation and preparation of apple and olive fruit blended jam. Global Journal Medical Research: L Nutrition and Food Science 15: 15-21.

Shandilya, N.K. \& Siddiq, M. 2020. Ripe banana processing, products, and nutrition. Handbook of Banana Production, Postharvest Science, Processing Technology, and Nutrition. New York: John Wiley \& Sons Ltd. pp. 99-116.

Shian, T.E. \& Abdullah, A. 2012. Antioxidant properties of three banana cultivars (Musa acuminata 'Berangan', 'Mas' and 'Raja') extracts. Sains Malaysiana 41(3): 319-324.

Shinwari, K.J. \& Rao, P.S. 2020. Rheological and physicochemical properties of a reduced-sugar sapodilla (Manilkara zapota L.) jam processed under high-hydrostatic pressure. Journal of Food Process Engineering 43(6): e13388.

Shinwari, K.J. \& Rao, P.S. 2018. Stability of bioactive compounds in fruit jam and jelly during processing and storage: A review. Trends in Food Science \& Technology 75: 181-193

Shivashankara, K. 2016. Metabolite profiling in banana. In Banana: Genomics and Transgenic Approaches for Genetic Improvement. Singapore: Springer. pp. 107-123.

Siddiqui, N.H., Azhar, I., Tarar, O.M., Masood, S. \& Mahmood, Z.A. 2015. Influence of pectin concentrations on physico-chemical and sensory qualities of jams. World Journal of Pharmacy and Pharmaceutical Sciences 4(6): 68-77.

Siddiqui, N.R., Muhammad, A., Khan, M.R., Ali, G.M., Mahmood, T., Shahzad, A. \& Jabbar, S. 2020. Differential gene expression of pectin esterase and changes in pectin during development and ripening stages of fruit in selected cultivars of banana. Food Science and Technology 40(4): $827-831$

Silva, I.G., Martins, G.A.D.S., Borges, S.V., Marques, G.R. \& Regis, I.S. 2012. Influence of passion fruit albedo, citric acid, and the pulp/sugar ratio on the quality of banana preserves. Food Science and Technology 32(2): 267-273.

Singh, R., Kaushik, R. \& Gosewade, S. 2018. Bananas as underutilized fruit having huge potential as raw materials for food and non-food processing industries: A brief review. The Pharma Innovation Journal 7(6): 574-580.

Sohedein, M.N.A., Wan, W.A.A.Q.I., Hui-Yin, Y., Ilham, Z., Chang, J.S., Supramani, S. \& Siew-Moi, P. 2020. Optimisation of biomass and lipid production of a tropical thraustochytrid Aurantiochytrium sp. UMACC-T023 in submerged-liquid fermentation for large-scale biodiesel production. Biocatalysis and Agricultural Biotechnology 23: 101496

Soradech, S., Nunthanid, J., Limmatvapirat, S. \& Luangtanaanan, M. 2017. Utilization of shellac and gelatin composite film for coating to extend the shelf life of banana. Food Control 73: 1310-1317.

Teodorowicz, M., Van Neerven, J. \& Savelkoul, H. 2017. Food processing: The influence of the Maillard reaction on immunogenicity and allergenicity of food proteins. Nutrients 9(8): 835.

Thompson, A.K., Supapvanich, S. \& Sirison, J. 2019. Banana Ripening: Science and Technology. Cham: Springer pp. 1-11.

Tifani, K.T., Nugroho, L.P.E. \& Purwanti, N. 2018. Physicochemical and sensorial properties of durian jam prepared from fresh and frozen pulp of various durian cultivars. International Food Research Journal 25(2): 826834.

Tin, H.S., Padam, B.S., Vairappan, C.S., Abdullah, M.I. \& Chye, F.Y. 2015. Effect of preparation and extraction parameters of banana (Musa balbisiana cv. Saba) inflorescence on their antibacterial activities. Sains Malaysiana 44(9): 1301-1307.

Toma, F.A., Ahmmed, R., Hasan, M.F., Haque, M.R., Monju, M.B. \& Surovi, M.S.H. 2018. Non-destructive maturity index of "Amritsagor" banana using RGB and HSV values. Journal of the Bangladesh Agricultural University 16(2): 293-302.

Wan-Mohtar, W.A.A.Q.I., Halim-Lim, S.A., Kamarudin, N.Z., Rukayadi, Y., Abd Rahim, M.H., Jamaludin, A.A. \& Ilham, Z. 2020. Fruiting-body-base flour from an Oyster mushroom waste in the development of antioxidative chicken patty. Journal of food science 85(10): 3124-3133.

Wan-Mohtar, W.A.Q.I., Klaus, A., Cheng, A., Salis, S.A. \& Halim-Lim, S.A. 2019. Total quality index of commercial oyster mushroom Pleurotus sapidus in modified atmosphere packaging. British Food Journal 121(8): 18711883.

Wan-Mohtar, W.A.A.Q.I., Mahmud, N., Supramani, S., Ahmad, R., Zain, N.A.M., Hassan, N.A., Peryasamy, J. \& HalimLim, S.A. 2018. Fruiting-body-base flour from an oyster mushroom - A waste source of antioxidative flour for developing potential functional cookies and steamed-bun. AIMS Agriculture and Food 3(4): 481-492.

Zhang, H., Chen, H., Wang, W., Jiao, W., Chen, W., Zhong, Q., Yun, Y.H. \& Chen, W. 2020. Characterization of volatile profiles and marker substances by HS-SPME/GC-MS during the concentration of coconut jam. Foods 9(3): 347.

Wan Abd Al Qadr Imad Wan-Mohtar, Joshini Pillai Balamurugan \& Nur Asyiqin Zahia Azizan

Functional Omics and Bioprocess Development Laboratory Institute of Biological Sciences

Faculty of Science

Universiti Malaya

50603 Kuala Lumpur

Malaysia 
Sarina Abdul Halim-Lim* \& Mohd Zahiruddin Mohd Saad Department of Food Technology

Faculty of Food Science and Technology

Universiti Putra Malaysia

43400 UPM Serdang, Selangor Darul Ehsan

Malaysia

Wan Abd Al Qadr Imad Wan-Mohtar \& Zul Ilham Bioresources and Bioprocessing Research Group Institute of Biological Sciences, Faculty of Science Universiti Malaya

Universiti Malaya

50603 Kuala Lumpur

Malaysia
Adi Ainurzaman Jamaludin \& Zul Ilham

Environmental Science and Management Program Institute of Biological Sciences, Faculty of Science

Universiti of Malaya

Universiti Malaya

50603 Kuala Lumpur

Malaysia

*Corresponding author; email: sarinalim@upm.edu.my

Received: 29 April 2020

Accepted: 25 September 2020 